\title{
Amendments of the limits of the genera Gyromitra and Pseudorhizina, with the description of a new species, Gyromitra montana
}

\author{
Harri Harmaja
}

\begin{abstract}
Department of Botany, University of Helsinki, SF-00170 Helsinki, Finland
Harmaja, H. 1973: Amendments of the limits of the genera Gyromitra and Pseudorhizina, with the description of a new species, Gyromitra montana. - Karstenia 13: 48--58. - Some new observations, relevant for specific, subgeneric and generic taxonomy, are presented on the characters of the species of Gyromitra Fr. and Pseudorhizina Jač. (Discomycetes, Pezizales), and the taxonomic significance of earlier known diagnostic features is dealt with and partly re-evaluated. On the basis of this information, it is considered that Pseudorhizina is a valid, independent genus, and that besides the type species, P. sphaerospora (Peck) Pouz., it should also contain Gyromitra californica (Phill.) Raitv. A tabulation comparing Gyromitra and Pseudorhizina is presented. It is also emphasized that, as previously suggested by the author, the genera Discina (Fr.) Fr. and Neogyromitra Imai should be included in Gyromitra, together forming a subgenus of their own, Gyromitra subg. Discina. Gyromitra gigas sensu McKnight is considered different from the true G. gigas, and is described as a new species, Gyromitra montana Harmaja. Seven new combinations, necessary due to the amendments of the two genera, are made: Gyromitra subgenus Discina (Fr.) Harmaja, Gyromitra apiculatula (McKn.) Harmaja, Gyromitra korfii (Raitv.) Harmaja, Gyromitra macrospora (Bub.) Harmaja, Gyromitra olympiana (Kan.) Harmaja, Gyromitra warnei (Perk) Harmaja and Pseudorhizina californica (Phill.) Harmaja.
\end{abstract}

\section{Pseudorhizina Jač.}

In my earlier paper on the delimitation of the genera of the family Rhizinaceae Bon. (Harmaja 1969a) I included the genus Pseudorhizina Jač. in the genus Gyromitra Fr. (nom. conserv.). However, at the same time I reported, evidently for the first time, that the type species of Pseudorhizina, viz. Gyromitra sphaerospora (Peck) Sacc., and $G$. californica (Phill.) Raitv. differed from the rest of the species of Gyromitra (sensu latissimo) in having no cyanophilic perisporeperiplasm complex outside their true spore wall. That structure is lacking during all stages of spore development in these two species, while in the rest of the species it gets developed towards spore maturity, first appearing at the spore ends. I also mentioned that a close relationship between these two species is indicated also by their macroscopic features. Having observed some additional features separating $G$. sphaerospora and $G$. californica from the rest of the Gyromitra species, and re-evaluated the earlier known facts, I now consider that there is justification for accepting the genus Pseudorhizina, in order to accommodate these two species. At present this genus is monotypic and is retained (e.g., EckBlad 1968) only because of the spherical shape of the spores of its type species, but, as is shown below, I cannot accord this character the slightest diagnostic value at the generic level!

Modern taxonomists specialized in the cup-fungi have usually placed $P$. sphaerospora (Peck) Pouz. and G. californica in different genera, though the striking resem- 
blances in their macroscopic and microscopic features (some of the latter were then still unknown) were pointed out by SмiтH (1949: 153, sub Helvella) in North America, where both species occur. Even the striking red staining of the stipe base, also reported in some European collections of $P$. sphaerospora (e.g., Pouzar 1961, Rahm 1970), is an almost constant feature in both species. Pouzar (1961) gives the status of forma to the redstiped ascocarps of $P$. sphaerospora, but nothing will be gained through such a nomenclatural procedure, especially as it has not been proved that the presence/absence of the red colour would depend on genetic factors. Indeed, I do not know at present of any other morphological differences between the two species than a few sporal ones.

The spores of $P$. sphaerospora are completely globose and rather small, being $8.0-$ $12.0 \mu \mathrm{m}$ in diameter, and the half-mature and mature spores, at least in dried specimens, each possess one central to slightly eccentric de Bary bubble (visible at least in water, $5 \% \mathrm{KOH}$, Melzer's reagent, and cotton blue; I do not know whether these de Bary bubbles, already observed by me before the publication of my earlier paper but not mentioned in it, have previously been reported in these species). In $G$. californica the spore shape is elliptical, slightly inequilateral; the spores are larger, ca. $13.5-17.5 \times 7.5$ $9.5 \mu \mathrm{m}$, and only a very small proportion contain one de Bary bubble towards maturity, mostly asymmetrically located. As a result of the different shapes of the spores of the two species, the inconspicuous sporal oil drops, when present at all and visible without being hidden by the conspicuous de Bary bubble (in P. sphaerospora they may be observed in many immature spores and occasional mature ones devoid of de Bary bubbles), are observed as a fairly distinct guttule at each end of the spores in G. californica but may be represented by only one larger drop in $P$. sphaerospora. In both species the position of the largest drop or drops is usually not symmetrical (see Fig. 1: a, b in Harmaja 1969a). One other difference between the species is the much wider distribution of $P$. sphaerospora, $G$. californica being restricted to northwestern North America. In addition, Dr. Smith, who has field experience of both species, writes (Sмiтн 1949) that P. sphaerospora usually grows on decaying wood, while the substrate of $G$. californica is more or less moist soil, either disturbed or undisturbed. Apart from possible minor differences in the anatomical features of the fruit body, a slight phenological difference might possibly be revealed if extensive material of both species from climatically similar areas were available for comparison (does P. sphaerospora generally occur somewhat later in the spring?).

For the reasons presented above, I consider Helvella sphaerospora Peck and Helvella californica Phill. congeneric, being the only two species belonging to the genus Pseudorhizina Jač., which accordingly is considered valid.

In Table 1. I have summarized the most important diagnostic differences between the redefined genera Pseudorhizina and Gyromitra (the distinctions between Pseudorhizina and the two genera Helvella and Rhizina Fr. being more readily apparent).

\section{Gyromitra Fr.}

Recently there has been a general trend among taxonomists to reduce the number of the genera of the family Rhizinaceae (e.g., Eckblad 1968, Harmaja 1969a, Raitvirr 1970, MaKnight 1971, Svrček \& Moravec 1972, Korf 1972). While most of these authors amalgamate the genus Neogyromitra Imai with the genus Discina (Fr.) Fr., MaKnIGHT reduces the number of genera in a different way; he unites the Gyromitra and Neogyromitra species because of their distinct pileus and stipe in Gyromitra, but keeps Discina apart, in its classical concept, i.e. accommodating discoid, indistinctly stipitate species.
Benedix (1969) has adopted a completely different approach, splitting genera extensively, but unfortunately some of his solutions appear to be extremely artificial, e.g. the location of the species perlata and leucoxantha in different genera, and the attribution of Discina and Rhizina to different families. Dissing (1972) also prefers narrow generic concepts and keeps Discina and Neogyromitra apart.

I am still of the opinion that Discina and Neogyromitra should not only be joined with each other, but also be merged in $G y$ romitra, which becomes much more homo- 
Table 1. A comparison of the most important characters separating the genera Pseudorhizina Jač. and Gyromitra Fr.

\begin{tabular}{|c|c|c|}
\hline & Pseudorhizina & Gyromitra \\
\hline $\begin{array}{l}\text { 1. Underside of the } \gg \text { cap» } \\
\text { as seen by the naked eye }\end{array}$ & $\begin{array}{l}\text { very finely whitish granulose or } \\
\text { tomentose }\end{array}$ & glabrous \\
\hline 2. Stipe & $\begin{array}{l}\text { with very prominent, high, sharp- } \\
\text { edged ribs continuing far outwards on } \\
\text { the underside of the cap, resembling } \\
\text { those of Helvella acetabulum }\end{array}$ & $\begin{array}{l}\text { smooth or with less conspicuous, low, } \\
\text { more or less blunt-edged ribs }\end{array}$ \\
\hline $\begin{array}{l}\text { 3. Stipe base in fresh ma- } \\
\text { ture fruit bodies }\end{array}$ & very often strikingly red & never with red colouration \\
\hline $\begin{array}{l}\text { 4. Length of most mature } \\
\text { spores (excluding any } \\
\text { perispore) }\end{array}$ & under $17 \mu \mathrm{m}$ & over $17 \mu \mathrm{m}$ \\
\hline $\begin{array}{l}\text { 5. Cyanophilic perispore- } \\
\text { periplasm complex }\end{array}$ & absent & present \\
\hline $\begin{array}{l}\text { 6. Contents of unripe } \\
\text { spores, the oil drops ex- } \\
\text { cluded (before any peri- } \\
\text { spore-periplasm has sur- } \\
\text { rounded the spores) }\end{array}$ & moderately cyanophilic & cyanophobic to weakly cyanophilic \\
\hline $\begin{array}{l}\text { 7. Oil drops in spores from } \\
\text { dried fruit bodies }\end{array}$ & $\begin{array}{l}\text { not always distinct; when present their } \\
\text { position very often asymmetrical, their } \\
\text { number and size also being more or } \\
\text { less variable even within species }\end{array}$ & $\begin{array}{l}\text { always present, with a fixed sym- } \\
\text { metrical position and size, usually also } \\
\text { constant number within species }\end{array}$ \\
\hline $\begin{array}{l}\text { 8. De Bary bubbles in } \\
\text { spores from dried fruit } \\
\text { bodies }\end{array}$ & $\begin{array}{l}\text { present towards maturity, either in al- } \\
\text { most all spores, or in a small pro- } \\
\text { portion }\end{array}$ & absent \\
\hline $\begin{array}{l}\text { 9. Paraphyses in } \mathrm{KOH} \\
\text { (e.g., } 5 \% \text { ) }\end{array}$ & $\begin{array}{l}\text { fading to more or less hyaline in a few } \\
\text { minutes, their contents sometimes re- } \\
\text { taining some of the original colour } \\
\text { and then being very pale greyish } \\
\text { brown, and homogeneous }\end{array}$ & $\begin{array}{l}\text { distinctly coloured, fading more slow- } \\
\text { ly, either red-brown due to encrusted } \\
\text { and/or more or less homogeneous in- } \\
\text { tracellular pigment, or with more or } \\
\text { less granular yellowish-brown contents }\end{array}$ \\
\hline $\begin{array}{l}\text { 10. Excipular tissue of ap- } \\
\text { propriately dried fruit } \\
\text { bodies as observed in } \\
\text { heated cotton blue }\end{array}$ & $\begin{array}{l}\text { not reviving easily, many hyphae re- } \\
\text { maining collapsed, perhaps at least } \\
\text { partly because they seem to have so- } \\
\text { mewhat thickened walls }\end{array}$ & $\begin{array}{l}\text { reviving more or less easily, hyphae } \\
\text { readily becoming inflated, having } \\
\text { more or less thin walls }\end{array}$ \\
\hline $\begin{array}{l}\text { 11. Cyanophilic »septal } \\
\text { belts» (see p. } 55 \text { ) on ex- } \\
\text { cipular hyphae }\end{array}$ & $\begin{array}{l}\text { conspicuous, being common and of } \\
\text { variable breadth }\end{array}$ & $\begin{array}{l}\text { scattered at most, often practically } \\
\text { lacking, always very narrow and in- } \\
\text { conspicuous }\end{array}$ \\
\hline
\end{tabular}

geneous when the species sphaerospora and californica are removed (see above). With the aid of some new observations, I shall attempt to clarify my earlier criticism of the four features which at present are the main criteria of those wanting to retain Discina or both Discina and Neogyromitra.

\section{Shape of the fruit body}

As pointed out earlier (Harmaja 1969a), the distinction between subsessile, shortly stipitate and distinctly stipitate species is very vague. This is evident also on p. 46 of MaKNIGHT's paper (1971), though that author still considers Discina as an independent genus. These differences, often used at the generic level, are quantitative only, de- 
pending on the degree to which the stipe has developed. All the species concerned seem to have at least the beginning of a stipe, and it is well known in the literature that, e.g., G. perlata (Fr.) Harmaja of the Discina group may posses a distinct stipe and not rarely even a gyromitroid hymenium, i.e. a conspicuously folded (in age it is as a rule at least slightly folded) and somewhat convex one. Also the pictures of Benedix (1969) representing $D$. melaleuca Bres. and Paradiscina intermedia Bened., likewise of the Discina group, show fungi fairly gyromitroid in appearance. On the other hand, MaKNIGHT (1971: 46) reports having found a fruit body of $D$. korfii Raitv. (as G. fastigiata [Krombh.] Rehm) of the Neogyromitra group with an entirely discinoid hymenium. The convex pileate, gyromitroid to lobate, or helvelloid, hymenium with an edge free at first and sometimes even later, too (in $G$. tasmanica Berk. \& Cooke, rarely also in $G$. ambigua [Karst.] Harmaja), and the discinoid one, as well as the small stipe and the long and/or thick stipe obviously only represent different stages in the same evolutionary series where the specialization of the fertile and sterile parts of the apothecium into a very distinct pileus and stipe and/or vice versa is in progress. The hymenium type is correlated with the size of the stipe, the hymenium being convex and mostly also attached to the stipe when the stipe is prominent and well developed.

Very important is that the anatomy of the more developed stipes in the esculenta-infula and Neogyromitra groups is not different from that of the small Discina stipe, these anatomical characters being always also identical with those of the excipulum. This fact confirms the opinion about a close relationship between the prominently stipitate and shortly stipitate groups. Moreover, it becomes unmasked that in all groups concerned this sterile part connecting the fruit body to the substrate is only a very weakly specialized organ, being only an elongation of variable length of the connecting point, composed of the same kind of tissue (textura intricata) as the outer layer, or excipulum, of the fertile part of the fruit body.

According to modern taxonomy, genera such as Helvella, Otidea and Sarcoscypha comprise subsessile to distinctly stipitate species, which are treated as congeneric be- cause of great similarities in other features, considered to have more diagnostic value at the generic level, especially the anatomy of the excipulum and the spore characters. A striking example showing how careful one should be when weighting the value of ascocarp shape at the generic level, is the well known case of Peziza proteana with its sparassioid form, which repeatedly had given rise to a new genus! The principle followed e.g. in the delimitation of the three genera mentioned above, should also be adopted in the present case, when, as I believe, it has indeed been proved that those microscopic features suggest a close relationship between the species of Gyromitra s. lato. One single, vague macroscopic quantitative character simply does not justify the distinction of genera. Eakblad (1968: 132) came to the same conclusion as regards the Pezizales generally. This is also the trend in the taxonomy of, say, the Agaricales and the Aphyllophorales.

\section{Apiculi of the spores}

As Le GaL (1947) has so excellently demonstrated, the apiculi of Discina and Neogyromitra spores are swellings at the spore ends in a perispore, the spaces between the perispore and the spore wall proper being filled with periplasm. Both the perispore and the periplasm are distinctly cyanophilic. I, in turn, have shown (Harmaja 1969a) that exactly the same structure is present in the spores of Gyromitra s. str. The much used attribute »apiculate» is, however, still employed to designate a supposed qualitative diagnostic difference between the »apiculate» spores of Neogyromitra and Discina and the »non-apiculate» ones of Gyromitra s. str. The differences concerned are, of course, only quantitative, depending on the different extent of the apical inflation of the perispore in different species. The difference »apiculate» versus »non-apiculate» is thus completely worthless at the generic level, especially as it has now been clearly demonstrated that there are species of the Neogyromitra and Discina groups that almost or completely lack »apiculi», namely $G$. gigas (Krombh.) Quél. sensu MaKnight 1971 (which will be described as a new species, G. montana Harmaja, later in this paper), D. apiculatula McKn., D. olympiana Kan., and obviously (according to the text and photo in BENEDIX 
1969) also $D$. melaleuca. In other words, in these species the perispore is only slightly more detached from the spore wall at the spore ends than it is elsewhere on the spore, often being even less inflated than in some species of Gyromitra s. str., especially G. ambigua! In addition, I have found that in few scattered spores of $G$. (s. str.) tasmanica (of which two specimens, from New Zealand and Chile, were kindly presented to our herbarium by Dr. H. Dissing, Copenhagen) the perispore had one to several papilla-like inflations, especially near and at the spore ends, the appearance of these spores thus being very much the same as that of the spores of $G$. caroliniana (Fr.) Fr. of the Neogyromitra group.

In this connection it may be mentioned that I have observed a moderately cyanophilic perispore in both mature and immature spores of Microstoma protractum, periplasm being, however, not discernible. In most spores, both ripe and immature, this perispore is everywhere smooth and tightly appressed to the true spore wall, thus not being easily observed. However, in a certain proportion of the spores it is detached at the spore ends, forming distinct, more or less regular apiculi. Small papilla-like swellings in the perispore, especially near the spore ends, like those described above in $G$. tasmanica, may often accompany these apiculi, or occur alone. In other words, in Microstoma protractum, the same hymenium, or even the same ascus, may contain spores of »Gyromitra type», »Neogyromitra gigas or Discina type» and »Neogyromitra caroliniana type»! Similar examples of the coexistence of different spore $\gg$ types» can easily be found elsewhere in Pezizales (see e.g. Le GaL 1947). It seems that when a perispore is present in Pezizales, it has frequently a tendency to become inflated, either constantly or occasionally, especially at the spore ends when the spore is elongated, the resultant structures, or inflations being regular or irregular in shape, the inflation pattern as a whole being, however, constant to a high degree within species.

\section{Reticulum on the spores}

The surface of the spores provides a wellknown, possible true, difference between the esculenta-infula group (= Gyromitra s. str.) and the Discina-Neogyromitra group (=
Discina sensu Eckblad 1968). Towards maturity the perispore in the latter group becomes distinctly to faintly rough, always with a reticulate pattern under the light microscope, evident at least at high magnifications. In apiculi this ornamentation is more delicate than elsewhere. In Gyromitra s. str. the perispore appears smooth. Even if this difference were supposed to be constant, as it at first appears to be, I should not wish to treat it as one of the most essential diagnostic generic characters. It should be noted that many authors who keep the esculenta-infula group and the Discina-Neogyromitra group in different genera, at the same time accept elsewhere in Pezizales the inclusion of both smooth and rough and even very clearly ornamented spores in one genus (e.g., Cheilymenia, Lamprospora, Octospora, Peziza and Pulparia). Moreover, the reticulum is very faint in some species of the Discina-Neogyromitra group, namely $G$. gigas sensu McKNight, D. olympiana and D. apiculatula, many mature spores in these species even appearing smooth unless studied very carefully. On the other hand, when I examined material of $G$. ambigua, a species of the esculenta-infula group whose spores are least dissimilar to those of some species of the Discina-Neogyromitra group (e.g. G. gigas), I observed that some aberrant spores had a distinct and regular reticulum, also observable as a roughness on the sides of the spores. After this observation I studied the surface of normal $G$. ambigua spores very carefully, and it did not seem impossible that, contrary to present opinion, at least a certain proportion of them may possess an extremely faintly reticulate perispore. Studies of the perispore with both the scanning and the transmission electron microscope would be most important to ascertain whether it really as a rule is ornamented in G. ambigua (and the rest of the species of the esculenta-infula group). If this proved to be a fact, the present character could definitely not be considered at the generic level any more, the differences observed only being quantitative in that case.

In Microstoma protractum I also observed the perispore to be more or less clearly reticulate, but only in those spores where the perispore also displayed swellings, apiculi and/or papillae (see above). This observation suggests that in Microstoma the form- 
ation of swellings in the perispore and the presence of a reticulum (as seen from above under a light microscope) are positively correlated with each other, in which case they could not be treated as two independent characters. The swellings and the reticulum may even be the same structure at a different stage of development and/or viewed at different angles, or two different structures resulting from one and the same phenomenon, the evident tendency of the membranous perispore to grow unevenly in places and thus become inflated and folded here and there. As a perispore is always a very thin and fairly soft and elastic structure as compared with the spore wall proper, very slight effects, even non-genetic factors, may be sufficient to alter its shape and make it apiculate and/or ornamented. A comparison of the esculenta-infula group and the DiscinaNeogyromitra group reveals that in the former group the perispore is smooth and only very slightly inflated at the spore ends. In some forms of $G$. esculenta (Fr.) Fr. it even lies at the same distance from the spore wall throughout. In the Discina-Neogyromit$r a$ group, with its generally larger spores, the perispore is rough and adorned with reticulum, and the apical swellings of the perispore are generally larger and more clearly defined. Three exceptional species with indistinct apiculi, $G$. gigas sensu MaKnight, $D$. olympiana and D. apiculatula, mentioned above in section 2 , are each very closely related to certain distinctly apiculate species, and moreover, all three have fainter reticuli than the latter (compare with the observations on Microstoma described above!). The situation seems to be similar with the fourth of these »exceptional» species, $D$. melaleuca. On the other hand, G. ambigua has the widest apiculi in the esculenta-infula group and is also the species with a tendency to develop a reticulum (see above).

Until studies with the scanning or perhaps preferably the transmission electron microscope are available, we can suppose that the reticulum may originate in at least two different ways: either it is a distinct substance accumulating on the perispore in the form of a reticulum, or it simply consists of minute swellings and folds in the perispore. In the latter case, which would accord with the apparent situation in Microstoma protractum described above, the difference smooth versus reticulate perispore loses much of its diagnostic value in taxonomy. However, in $R h i$ zinaceae smoothness and roughness of the perispore is obviously genetically controlled and more constant within the species than in Microstoma protractum, and accordingly this feature deserves recognition as an infrageneric diagnostic character. Uneven growth is well known in the hymenia of many species, especially $G$. esculenta, resulting in folded, or gyrose hymenia or pilei, but has quite rightly long been considered to lack validity as a generic character.

\section{Number of oil drops in the spores}

Apart from the presence versus absence of the reticulum, the difference in the number of oil drops (whose occurrence within the species in question is very constant), is the only apparently reliable criterion according to which each species of Gyromitra s. lato may be divided into one or other of two groups. The differences are well known, being as follows: In the esculenta-infula group there are two equal-sized oil drops symmetrically located on both sides of the median plane of the spores, while in the rest of the species, i.e. the Discina-Neogyromitra group, there is an odd number of oil drops, either (most commonly) three guttules with a larger one in the middle of the spore and two smaller ones situated symmetrically on both sides of the large one near the spore ends, or a single large central drop. Some species (D. melaleuca and Paradiscina intermedia, Benedix 1969) which evidently belong here (the structure of their excipulum is unfortunately not adequately known) seem to have a good proportion of biguttulate spores, but the drops are then both of unequal (rarely equal) size and asymmetrically located in a way which clearly suggests that they are derived from three original drops, the larger of the two having been formed by the merging of a small lateral drop in a large central one. This situation has been excellently described and illustrated by BENEDIX (1969).

However, I do not consider the difference in the number of oil drops in Gyromitra s. str. and Discina sensu Eakblad (1968) diagnostic at the generic level, since it is a purely quantitative difference, clearly depending on differences in spore size and shape. Some other genera contain species with different 
numbers of oil drops (e.g. Helvella and Leucoscypha), others even have species with homogeneous or variably guttulate spore contents (e.g. Peziza), and modern taxonomists do not generally split these genera according to this character. It seems evident that in many genera of Pezizales, Gyromitra s. lato included, the oil drops, when present, have a tendency to fill the space available inside the spore, and to do this as economically as possible. When the spore is globose, one drop is commonly present. When it is subglobose or elliptical to somewhat oblong, one large elongated drop is (as usual in Helvella) or two drops are often a constant feature. When the spore is more or less fusiform, it is easy to understand that a three-guttulate pattern gives the most even distribution of oil within the spore, the largest drop being located in the middle, in the broadest point of the spore. It also appears that the spores in many genera of Pezizales often tend to be globose when small, subglobose to elliptical and oblong when of moderate size, and subfusiform to fusiform when large. These trends (there may also be an upper limit to the diameter of an oil drop) may well explain the fact that the smaller, mostly elliptical to oblong spores of the species of the esculenta-infula group have two equal drops only (also those of G. ambigua, which, however, are more or less fusiform; this species resembles, however, the Discina-Neogyromitra group more than the rest of the species of its group, and G. ambigua might perhaps be considered as a connecting link between the infula and Neogyromitra groups) while the larger, more or less fusiform spores in the Discina-Neogyromitra group have the three-dorp pattern or, infrequently, that with one large central drop, which is obviously derived from the three-dropped one. Rhizina undulata Fr. of the same family and same evolutionary sequence has long, narrow spores with a tendency to partly parallel walls. It has accordingly one more oil drop, i.e., four of them, two large ones in the middle part of the spore and two small ones, each near the narrow ends. The small-spored but three-guttulate $D$. melaleuca and Paradiscina intermedia as described and depicted by BENEDIX (1969) seem to be derived from some typical member of the Discina group and to have this number of drops as a relic character. This is supported by the fact that in these species the evolution towards the evidently more suitable (for these small spores) biguttulate condition is already in progress, judging from the descriptions and photographs of BENEDIX (1969).

A similar situation exists in, e.g., the genus Helvella, where only $H$. macropus has large (for that genus) and fusiform spores, which are three-guttulate with the large drop in the middle. In addition, the spores of that species have very small warts, which, too, are unique in Helvella (according to Dissing \& Nannfeldt 1966, Smith Weber 1972, and my own observations). In spite of this, Dissing (1966) and most recent authors quite correctly do not consider this deviating species worts a genus of its own (in fact, they do not even regard it necessary to have a monotypic section for this species!). Why should we, contrary to Helvella, split Gyromitra with regard to the number of oil drops?

\section{Relations of Gyromitra s. str. and Discina sensu Eckblad}

The species of the esculenta-infula group are obviously very similar to those of the Discina-Neogyromitra group in respect of habitus, colours, spore characters, anatomy and ecology, as has already been pointed out by me (Harmaja 1969a). A couple of common features may be added. Under ultra-violet light (the wave-length of the lamp being $254 \mathrm{~nm}$ ). the dried fruit bodies of at least the following species were found to have more or less similar reactions in my so far somewhat preliminary studies: G. esculenta, G. tasmanica, G. infula (Fr.) Quél., $G$. ambigua, $G$. gigas, $G$. gigas sensu McKnight, $G$. perlata, $G$. leucoxantha (Bres.) Harmaja, D. apiculatula, D. korfii, D. macrospora Bub., $D$. olympiana and $D$. warnei (Peck) Sacc. (in addition, Helvella leucomelaena, G. californica, and P. sphaerospora, in which only the hymenium and underside were studied). These reactions were roughly as follows: hymenium showing its natural colour mixed with violet tints (at least in G. infula, $G$. gigas and $D$. warnei with faint olive tinge in addition); underside as well as stipe and context pale, with mixed pale violet and yellow to orange-yellow tints (the yellow and orange-yellow tints indistinct in $G$. infula, $G$. ambigua and D. warnei; these bright colours generally tend to be more distinct in 
specimens collected long ago, the violet tinge prevailing for a certain time after drying); basal tomentum violet. Rhizina undulata seems to have different reactions, since the underside of the fruit body appeared completely dark violet, and a yellow zone was seen in the upper part of the context. The reaction of its hymenium is similar to that of the above species, showing a faint olive tint, too.

Preliminary studies showed that curious elements, cyanophilic »septal belts», were present in all the species examined in the esculenta-infula and Discina-Neogyromitra groups, but were always infrequent and inconspicuous, as was stated in the tabulation of the diagnostic characters of the genera Pseudorhizina and Gyromitra. In G. esculenta and $D$. olympiana they occur occasionally; in other species, e.g. G. infula and $G$. leucoxantha, only one or two of them were observed per anatomical preparation. They are also rare in Rhizina undulata (where, however, other cyanophilic matter occurs, e.g. the contents of certain hyphae), but, as stated in the comparative tabulation, they were frequent and conspicuous in the genus Pseudorhizina. These structures are simply strongly cyanophilic matter surrounding the hyphae of the excipulum just at the septa in the form of a ring. Sometimes, such as in Gyromitra s. lato, they seem to be no broader than the thickness of the septal wall, i.e., they are extremely narrow; in other cases they are broader, extending equally far along the hypha on both sides of the septa. They never seem to occur around all the septa but only a proportion of them. (I have also found them in e.g. Tarzetta [Pustularia] catinus, Otidea onotica, O. indivisa, O. phlebophora, $O$. cf. leporina, $O$. spp. indet., Helvella acetabulum, $H$. lacunosa, Peziza badia and Microstoma protractum.)

On the other hand, a couple of evident slight differences between the esculentainfula and Discina-Neogyromitra groups must be reported. Though all the species of the latter group have not yet been examined in this respect, it appears that in $\mathrm{KOH}$ (e.g., $5 \%$ ) the pigment of the paraphyses of these species is most evident in the contents of their upper parts, being yellowish brown and more or less granular. The pigment is soluble in this mounting medium, as can be seen, besides microscopically, often also with the naked eye as the darkening of the medium near the cut surface against a light source or white background (e.g. paper), provided that the section is sufficiently thick containing a large amount of paraphyses to provide the pigment enough. In the species of the esculenta-infula group the pigment of the paraphyses is likewise soluble in $\mathrm{KOH}$ (perhaps slightly less easily?), but it is usually darker being most evident as a reddish brown colour in the encrustments, and this colour is sometimes also present in the invariably homogeneous contents of the paraphyses. Smith (1949) noted that the contents of the paraphyses of $\gg G$. gigas» (= obviously essentially $G$. gigas sensu McKNiGHT) are yellow and granular in $\mathrm{KOH}$, while EckBLAD (1968) reports that the paraphyses of Discina possess »brown or yellow granular contents», failing, however, to tell the mountant. Kanouse (1948) and Smith (1949) also write that $G$. esculenta and $G$. infula have red to reddish brown paraphyses in $\mathrm{KOH}$. All these observations suggest that there might be a true difference in the pigment (or pigments) of the paraphyses, and it is accordingly hoped that the constancy of this difference would be tested by those studying these fungi. The same applies to the occurrences of red (not reddish brown!), often thread-like particles (some connection with DNA?) which I observed in the asci of $G$. esculenta, $G$. tasmanica, $G$. infula and $G$. ambigua, outside the developing spores, when they were mounted in $5 \% \mathrm{KOH}$, while they were absent from the asci of the species of the Discina-Neogyromitra group. However, if these two chemical differences prove to be valid, their significance should not be overemphasized. Chemical differences are commonly revealed, e.g. by the same $\mathrm{KOH}$ treatment, in even very closely related species of the same genera in, for instance, lichens and agarics.

In summary, there are two rather easily observed and constant differences between the species of the esculenta-infula group and those of the Discina-Neogyromitra group, in the characters of (1) the oil drops in the spores and (2) the surface of the perispore (it is, however, not sure whether this difference is true even at the light microscope level; see the comment on $G$. ambigua in the 
third section), and two additional ones, the validity of which has so far not been definitely proved, in the $\mathrm{KOH}$ reactions of (3) the paraphyses and those of (4) the extrasporal contents of the asci. For the reasons stated earlier in this paper, I do not consider these differences sufficient for a generic distinction but regard them as infrageneric, and as they seem to be correlated with each other, it appears that the best solution is to consider these two groups of species as two subgenera.

While the esculenta-infula group will constitute Gyromitra subg. Gyromitra, G. esculenta being the type species of the genus, the subgeneric name Gyromitra subg. Discina (Fr.) Harmaja, n. comb., is proposed for the Discina-Neogyromitra group. 》Gyromitra subg. Lacunaria Fr.» (FrIEs 1872: 174) is an invalid name, a nomen nudum, to be rejected since FrIEs failed to supply any description or diagnosis (International Code of Botanical Nomenclature: Art. 36) and only writes: »Hae duae species peculiare subgenus, Lacunaria dictum, forment.». The two species referred to were commented earlier in his paper and are G. labyrinthica Fr., n. sp. (= G. gigas, as already judged by NANNFELDT, 1932 ), and G. caroliniana.

\section{New combinations, with notes on some taxa concerned}

Gyromitra subgenus Discina (Fr.) Harmaja, n. comb. (Peziza A. Discina Fries, Systema mycologicum ... 2: 38. 1822. - Lectotype Peziza perlata Fr., selected indirectly by FrIES himself [1849] through restricting to monotypic the taxon which he at the same time gave the generic status.)

Gyromitra apiculatula (McKn.) Harmaja, n. comb. (Discina apiculatula McKnight, Mycologia 61: 616. 1969. - Holotype [BPI] studied.)

Gyromitra korfii (Raitv.) Harmaja, n. comb. (Discina korfii Raitviir, Tartu riikliku ülikooli toimetised 268. Botaanika-alased tõõd 9: 371. 1970. - Holotype and two paratypes [CUP] studied.) - In the original description the only morphological difference given between this North American species and the very closely related $G$. gigas was the more slender spores. My observations suggest, however, that the spores of $G$. korfii are also slightly shorter (which, to be fair, is also apparent in RaITVIIR's spore diagram), the reticulate ornamentation of the perispore is slightly more delicate, and that its paraphyses expand more abruptly, even to a capitate head, which is broader, up to ca. $13 \mu \mathrm{m}$ in diameter (in Melzer's). This average difference in the paraphysis morphology is analogical with that between G. montana and $G$. gigas (see below) and between $G$. infula and G. ambigua (Harmaja 1969b, Fig.
2). McKnight (1971) treats for the most part $G$. korfii under the name $G$. fastigiata (Krombh.) Rehm, but this is an obvious misapplication of that name, carefully proved by Svrček and Moraveg (1972): (The European specimens of $G$. fastigiata sensu McKNIGHT most probably represent the true G. gigas.)

Gyromitra macrospora (Bub.) Harmaja, n. comb. (Discina macrospora Bubák, Ann. mycol. 2: 395. 1904. — Lectotype [BPI] studied.) - Besides the obvious spore differences between this species and the closely related $G$. perlata, so thoroughly described by MaKNight (1969), I found also the tips of the paraphyses different in these two species. At least in the type of $G$. macrospora they are somewhat thinner than those of $G$. perlata, being only ca. $4.0-8.0 \mu \mathrm{m}$ in diameter (in Melzer's).

Gyromitra olympiana (Kan.) Harmaja, n. comb. (Discina olympiana Kanouse, Mycologia 39: 648. 1947. - Fragment of holotype [MICH] studied.)

Gyromitra warnei (Peck) Harmaja, n. comb. (Peziza warnei Peck, New York State Mus. Rep. 30: 59. 1878. - Part of holotype [NYS] studied.)

Pseudorhizina californica (Phill.) Harmaja, n. comb. (Helvella californica Phillips, Trans. Linnean Soc. II. Bot. 1: 423. 1880.)

\section{Description of a new species, Gyromitra montana Harmaja}

Gyromitra montana Harmaja, n. sp. Valde similis Gyromitrae gigantis, sed $a b$ ea differt forma sporarum plus ellipsoidea, api- culis sporarum dissimilibus et minoribus, reticulo perisporae leniter tenuiore, paraphysibus apicibus crassioribus, fructificatione 
praecociore et distributione dissimili in regionibus montosis. - Holotype: 》Gyromitra gigas (Krombh.) Quél. / [U.S.A.,] Wyoming: West side of Teton Pass, / Teton Co. / on soil around and under snowbanks, / conifer forest. / Coll.: K. B. McKnight \& J. B. McKnight [VI.-VII. 1967] / Det.: K. H. McKnight 10351»( $\mathrm{H}$; isotypes $\mathrm{K}, \mathrm{BPI})$.

This species, a specimen of which was kindly presented to our herbarium by Dr. K. H. MaKnight, differs from $G$. gigas through, the perispore excluded, slightly more ellipsoid, less fusiform spores with somewhat broader ends, the inconstancy of the presence of the spore apiculi, the variable and often irregular shape and smaller size of the latter when discernible, the slightly more delicate ornamentation of the perispore, the thicker tips of the paraphyses which may even be capitate and attain a breadth of ca. $13 \mu \mathrm{m}$ (as measured in Melzer's reagent) while in $G$. gigas they are clavate to subcapitate and only reach a diameter of ca. 10 $u \mathrm{~m}$, the earlier fruiting time often near melting snow (sometimes even developing fruit bodies under the snow!), and the different distribution in the mountains of western North America and Austria in Europe (the fruiting time and the distribution according to MaKnight 1971). From $G$. korfii it can be distinguished through similar differences as from $G$. gigas as regards the spore shape, features of the spore apiculi, and the characters of occurrence, but also because of the longer and broader spores of $G$. montana. As compared with $G$. olympiana it is especially to be noted that the latter has a discinoid ascocarp, longer and broader spores slightly more fusiform in shape, and thinner tips of the paraphyses. Also G. api- culatula is closely related to $G$. montana, but is easy to recognize when it is kept in mind that the former has a discinoid fruit body and thinner tips of the paraphyses.

This new species is Gyromitra gigas sensu Smith (1949) and MaKnight (1971). However, as $G$. gigas has originally been described on the basis of Bohemian material, it is exclusively that material that is to be consulted when interpreting and typifying this name. The current European meaning of $G$. gigas, different from that of these American authors, is correct and to be maintained as is obvious on the basis of e.g. a study of Cizechoslovakian authors (SvrčEK a Moravec 1972). Also specimens now referable to $G$. korfii have in North America been taken for $G$. gigas, but it appears that in fact the occurrence of the true $G$. gigas on that continent still remains to be proved, as also supposed by RaItvirr (1970).

As the description of MaKnight (1971, as $G$. gigas) of $G$. montana, with photographs and the map of its North American distribution, is excellent and obviously based on homogeneous material, I do not feel it imperative to prepare any from my side. However, some new observations on the characters of this species are presented earlier in this paper, including its comparison with the closest relatives.

Acknowledgements. - I wish to express my sincere thanks to the following persons who most kindly provided herbarium material for this study: Dr. Henry Dissing (C), Dr. John H. Haines (NYS), Prof. Dr. Richard P. Korf (CUP), Dr. Paul L. Lentz (BPI), Dr. Kent H. McKnight (BPI), Dr. Robert L. Shaffer (MICH), and Dr. Stanley J. Smith (NYS). I am indebted also to Mrs. Anna A. Damström, M. A., for revising the English of this paper.

\section{REFERENCES}

Benedix, E. H. 1969: Art- und Gattungsgrenzen bei höheren Discomyceten, III. - Kulturpflanze 17: 253-284.

Dissing, H. 1966: The genus Helvella in Europe with special emphasis on the species found in Norden. - Dansk Bot. Ark. 25: 1-172.

$\longrightarrow$ - 1972: Specific and generic delimitation in the Helvellaceae. - Persoonia 6: 425$432+23$.

Dissing, H. and Nannfeldt, J. A. 1966: Helvella cupuliformis sp. nov., $H$. villosa (Hedw. ex O. Kuntze) comb. nov., H. macropus (Pers. ex Fr.) Karst., and their allies. - Svensk Bot. Tidskr. 60: 325-337 + I-III.

Eckblad, F.-E. 1968: The genera of the operculate
Discomycetes. A re-evaluation of their taxonomy, phylogeny and nomenclature. - N. Mag. Bot. 15: 1-191.

Fries, E. M. 1849: Summa vegetabilium Scandinaviae, seu enumeratio systematica et critica plantarum quum cotyledonearum, tum nemearum inter Mare Occidentale et Album, inter Eidoram et Nordkap, hactenus lectarum, indicata simul distributione geographica. 2. - pp. 259-572. Holmiae \& Lipsiae.

— 1872: Queletia, novum Lycoperdaceorum genus, accedit nova Gyromitrae species. Öfvers. Kongl. Vetenskaps-Akad. Förhandl. 28 (1871): $171-174+\mathrm{I}$. 
HaRmaja, H. 1969a: A wider and more natural concept of the genus Gyromitra Fr. Karstenia 9: 9-12.

$\longrightarrow-1969 \mathrm{~b}:$ A neglected species, Gyromitra ambigua (Karst.) Harmaja, n. comb., and G. infula s. str. in Fennoscandia. - Karstenia 9: $13-19$

Kanouse, B. 1948: Some studies in the genus Helvella. - Pap. Michigan Acad. Sci. Arts Lett. 32: 83-90.

Korf, R. P. 1972: Synoptic key to the genera of the Pezizales. - Mycologia 64: 937994.

LE GAL, M. 1947: Recherches sur les ornementations sporales des Discomycètes operculés. - Ann. Sci. Nat. XI: Bot. 8: 73-297.

MaKnight, K. H. 1969: A note on Discina. Mycologia 61: 614-630.

$\longrightarrow-1971:$ On two species of false morels (Gyromitra) in Utah. - Great Basin Nat. 31: $35-47$.

NAnnfeldT, J. A. 1932: Bleka stenmurklan, Gyro- mitra gigas (Krombh.) Cke. - Friesia 1: $34-45$.

Pouzar, Z. 1961: Systematická hodnota ucháčovce šumavského - Helvellella gabretae (Kavina) Pouz. et Svr. The taxonomical value of Helvellella gabretae (Kavina) Pouz. et Svr. - Česká Mykol. 15: 42-45.

RAнм, E. 1970: Ueber einige Rhizinaceae aus dem Hochtal von Arosa. - Schweiz. Zeitschr. Pilzk. 48: $77-87+\mathrm{I}$.

RaItviIR, A. 1970: Once more on Neogyromitra caroliniana. - Tartu riikliku ülikooli toimetised 268. Botaanika-alased tõõd 9: 364373.

Smith, A. H. 1949: Mushrooms in their natural habitats. - 626 pp. Portland.

Smith Weber, N. 1972: The genus Helvella in Michigan. - Michigan Bot. 11: 147-201.

Svrček, M. a Moravec, J. 1972: O druhu Helvella fastigiata Krombholz. Ueber die Helvella fastigiata Krombholz. - Česká Mykol. 26: $1-8+\mathrm{I}$. 